\title{
Ruthenium-catalyzed Atom Transfer Radical Addition Reactions
}

\author{
Kay Severin*
}

\begin{abstract}
Certain ruthenium complexes are potent catalysts for atom transfer radical addition (ATRA) and cyclization (ATRC) reactions, in particular if they are used in conjunction with reducing agents such as magnesium. This short overview summarizes recent developments in this area with special focus on contributions from our laboratory.
\end{abstract}

Keywords: ATRA · ATRC · Cyclopropanes · Radical reactions · Ruthenium

\section{Introduction}

Organohalides can be coupled to olefins via atom transfer radical addition (ATRA) reactions (Scheme 1a). This type of reaction was first described by Kharasch and his group in the 1940s using free radical initiators or light. ${ }^{[1]}$ Later, it was shown that transition metal complexes are able to catalyze ATRA reactions. ${ }^{[2]}$ The metal complexes act as halogen atom transfer reagents and reduced the amount of side products (e.g. polymers). Over the last years, metal catalysts for ATRA reactions have been optimized and interesting applications in organic synthesis have been developed. ${ }^{[3]}$ Of particular interest is the intramolecular ATRA, commonly referred to as atom transfer radical cyclization (ATRC, Scheme 1b). This reaction is particularly efficient for the construction of five- and six-membered ring systems. ${ }^{[4]}$ ATRA and ATRC reactions are catalyzed by complexes of different transition metal elements, with the highest activity typically found for complexes of copper and ruthenium. ${ }^{[3]}$ Recent developments with Ru-based catalysts are summarized below.

\section{Reducing Agents in Ru-catalyzed ATRA Reactions}

The first report about a Ru-catalyzed ATRA reaction was published in 1973. ${ }^{[5]}$ It was shown that $\mathrm{RuCl}_{2}\left(\mathrm{PPh}_{3}\right)_{3}$ catalyzes the addition of $\mathrm{CCl}_{4}$ and $\mathrm{CHCl}_{3}$ to terminal olefins with good selectivity. Since then, numerous other $\mathrm{Ru}$ complexes have been

${ }^{\star}$ Correspondence: Prof. Dr. K. Severin Institut des Sciences et Ingénierie Chimiques École Polytechnique Fédérale de Lausanne (EPFL) $\mathrm{CH}-1015$ Lausanne

Tel.: +41216939312

Fax: +41216939305

E-mail: kay.severin@epfl.ch evaluated for their ability to catalyze ATRA and ATRC reactions. [3,6] Some selected catalysts are depicted in Fig. 1. The studies on catalyst optimization revealed early on that catalyst stability was more problematic than catalyst activity. The half-sandwich complex $\mathrm{Cp} * \mathrm{RuCl}\left(\mathrm{PPh}_{3}\right)_{2}$, for example, was shown to catalyze the addition of $\mathrm{CCl}_{4}$ to styrene with a high initial turnover frequency of $400 \mathrm{~h}^{-1}$. However, the total turnover number did not exceed 1700. ${ }^{[6 n]}$ In 2006, we showed that the additive azobis(isobutyronitrile) (AIBN) allows the

a. Atom Transfer Radical Addition Reaction (ATRA):<smiles>[R]C=C=[C+]=[X]</smiles>

b. Atom Transfer Radical Cyclization Reaction (ATRC):
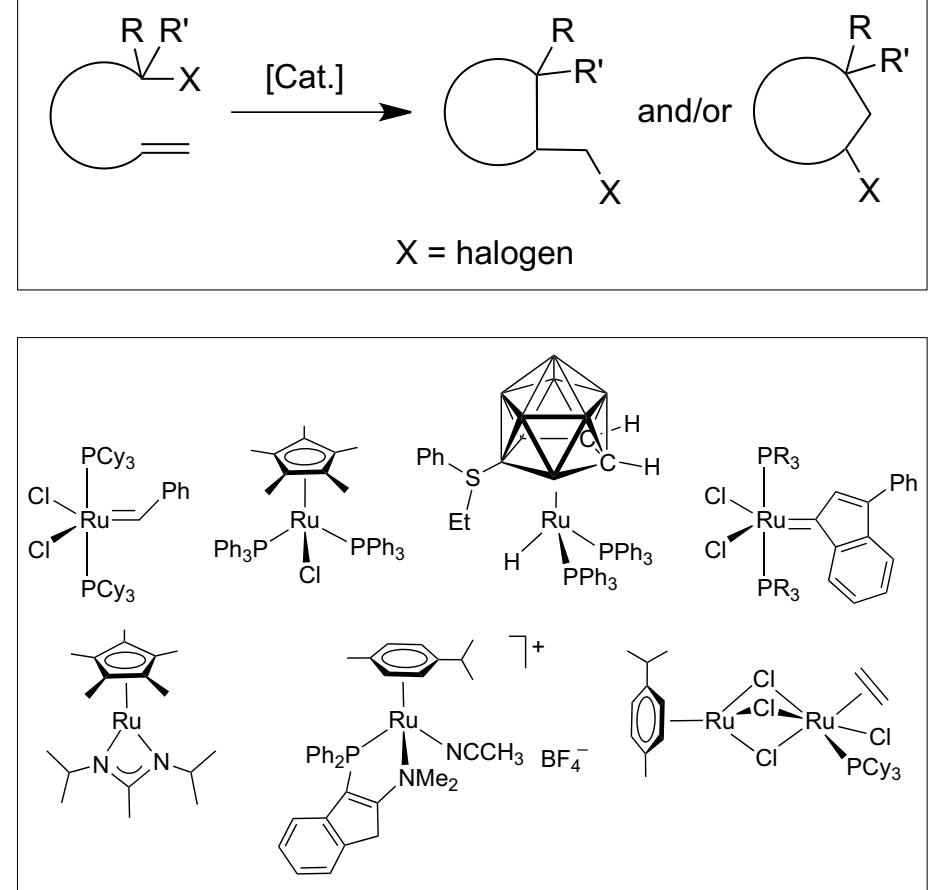

Scheme 1. ATRA and ATRC reactions.

Fig. 1. Selected ruthenium catalysts for ATRA reactions. 
of the olefinic substrate, which may result in an increased amount of polymeric side products. The latter process is particularly problematic for highly reactive olefins such as methacrylates. As alternative additive, we have introduced magnesium powder, which is cheap, non-toxic, and easy to handle and to separate. Similar to AIBN, the additive $\mathrm{Mg}$ allows the catalyst loading to be reduced dramatically. ${ }^{[9]}$ Recently we have shown that manganese powder can be an interesting alternative to $\mathrm{Mg} .{ }^{[10]} \mathrm{It}$ should be pointed out that AIBN and $\mathrm{Mg}$ have also been used with great success in $\mathrm{Cu}$-catalyzed ATRA reactions. [11]

The combination of $\mathrm{Cp}^{*} \mathrm{RuCl}_{2}\left(\mathrm{PPh}_{3}\right)$ with $\mathrm{Mg}$ represents one of the most powerful catalytic systems for ATRA/ATRC reactions described so far. ${ }^{[9 c]}$ The system is also advantageous from a practical point of view because the $\mathrm{Ru}^{\mathrm{III}}$ complex $\mathrm{Cp}^{*} \mathrm{RuCl}_{2}\left(\mathrm{PPh}_{3}\right)$ is air-stable and easy to synthesize from commercial precursors. We have performed a mechanistic study of $\mathrm{Cp}^{*} \mathrm{RuCl}_{2}\left(\mathrm{PPh}_{3}\right) / \mathrm{Mg}$-catalyzed ATRA reactions using the addition of ethyl trichloroacetate to styrene as a representative reaction. The key findings are summarized in Scheme 2. In a first step, the $\mathrm{Ru}^{\mathrm{III}}$ complex $\mathrm{Cp}^{*} \mathrm{RuCl}_{2}\left(\mathrm{PPh}_{3}\right)$ is reduced by $\mathrm{Mg}$ to the (hypothetical) $\mathrm{Ru}^{\mathrm{II}}$ complex $\mathrm{Cp} * \mathrm{RuCl}\left(\mathrm{PPh}_{3}\right)$ ('activation'). The $\mathrm{Ru}^{\mathrm{II}}$ complex starts the catalytic cycle by rapidly reacting with ethyl trichloroacetate to give complex $\mathrm{Cp}^{*} \mathrm{RuCl}\left(\mathrm{PPh}_{3}\right)$ along with the radical $\bullet \mathrm{CCl}_{2} \mathrm{CO}_{2} \mathrm{Et}$. The equilibrium for this reversible chloro atom transfer reaction is completely on the side of the $\mathrm{Ru}^{\mathrm{III}}$ complex $\left(k_{2}>k_{-2}\right)$. The rate-limiting step of the reaction is the subsequent coupling between $\cdot \mathrm{CCl}_{2} \mathrm{CO}_{2}$ Et and styrene $\left(k_{3}\right)$. This assumption is supported by the UV-Vis and ESR experiments, which show that the $\mathrm{Ru}^{\mathrm{III}}$ complex is the resting state of the reaction. The main product of the reaction is formed in a chloro atom transfer between $\mathrm{Cp} * \mathrm{RuCl}_{2}\left(\mathrm{PPh}_{3}\right)$ and the benzyl radical. The equilibrium of this reversible reaction is on the side of $\mathrm{Ru}^{\mathrm{II}}$ complex $\left(k_{4}>k_{-4}\right)$. The carbon-centered radical $\bullet \mathrm{CCl}_{2} \mathrm{CO}_{2} \mathrm{Et}$ can undergo a termination reaction instead of coupling with styrene. Termination reactions would lead to an accumulation of $\mathrm{Ru}^{\mathrm{III}}$ complexes, but the excess of $\mathrm{Mg}$ avoids this problem. The role of $\mathrm{Mg}$ is therefore twofold: a) it activates the $\mathrm{Ru}^{\mathrm{III}}$ catalyst precursor, and $b$ ) it regenerates the $\mathrm{Ru}^{\mathrm{II}}$ species during the reaction.

\section{Sequential Reactions involving Ru-catalyzed ATRA Reactions}

ATRA and ATRC reactions are increasingly being employed in advanced organic syntheses. [3a] Several groups have investigated sequential reaction involving

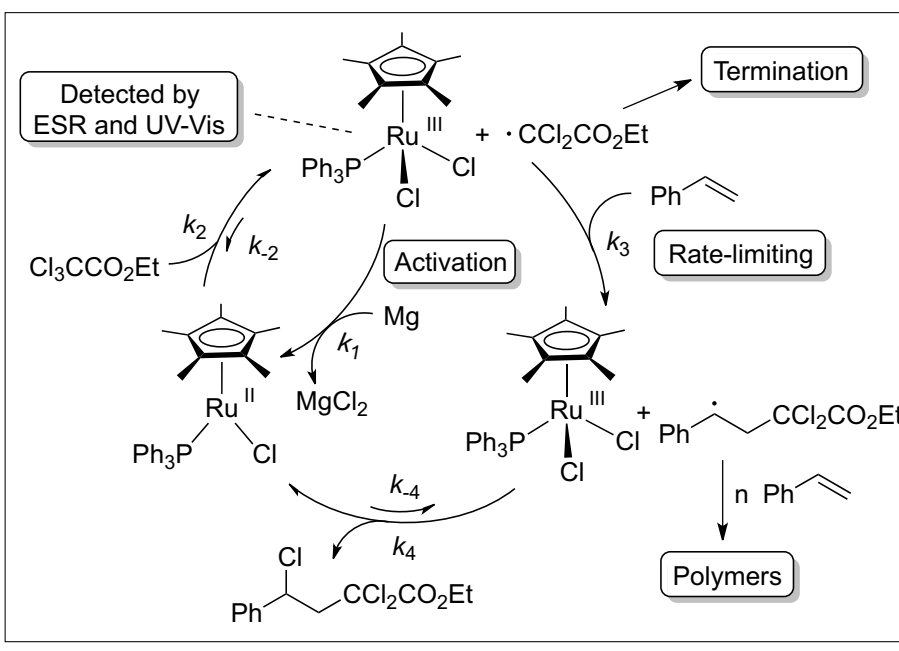

Scheme 2. Proposed mechanism for the ATRA of ethyl trichloroacetate to styrene catalyzed by $\mathrm{Cp}^{*} \mathrm{RuCl}_{2}\left(\mathrm{PPh}_{3}\right)$ in the presence of $\mathrm{Mg}$.

a $\mathrm{Ru}$-catalyzed radical process. We have shown in 2009 that ATRA reactions can be followed by a dechlorination reaction to give cyclopropanes in a one-pot-twostep procedure (Scheme 3a). ${ }^{[12]}$ Key to success was again the utilization of $\mathrm{Mg}$ as additive. The ATRA reaction between a terminal olefin and an activated organodichloride $\mathrm{Cl}_{2} \mathrm{CH}(\mathrm{EWG})$ (EWG = electron withdrawing group) provides a 1,3-dichloride. When tetrahydrofuran is added to the mixture at the end of the ATRA step, a dechlorination reaction takes place to give cyclopropanes. For highly activated substrates such as $\mathrm{Cl}_{3} \mathrm{CCO}_{2} \mathrm{Et}$ or $\mathrm{Cl}_{2} \mathrm{C}(\mathrm{CN})_{2}$, manganese should be employed as reducing agent instead of magnesium. ${ }^{[10]}$ These one-pot procedures are applicable to a wide range of substrates, and the reactions can also be used to synthesize bicyclic cyclopropanes. An advantage of this method is the fact that functionalized cyclopropanes can be obtained without the utilization of potentially problematic diazo compounds. The latter point is of particular importance for trifluoromethyl-substituted cyclopropanes, which can be prepared from the commercial anesthetic halothane

$\left(\mathrm{BrClCHCF}_{3}\right)$ instead of the toxic trifluoromethyl diazomethane. ${ }^{[13]}$

Sequential reactions involving two ATRA/ATRC steps have been used to build complex molecules. For example, functionalized lactams were obtained by ATRC-ATRC ${ }^{[14]}$ or by ATRC-ATRA reaction sequences. ${ }^{[15]}$ We have recently reported that it is possible to perform double Kharasch reactions with dichlorinated compounds in a purely intermolecular fashion (Scheme 3b). ${ }^{[16]}$ The ATRA-ATRA reaction sequence can be carried out with two types of olefins allowing the preparation of structurally diverse 1,5-dichlorides. The latter are interesting synthetic precursors as demonstrated by the synthesis of cyclopentanes by Mg-induced dechlorination.

In 1999, it was reported that the $1 \mathrm{st}$ generation Grubbs metathesis catalyst $\mathrm{RuCl}_{2}(=\mathrm{CPh})\left(\mathrm{PPy}_{3}\right)_{2}$ can mediate ATRA reactions. ${ }^{[17]}$ Subsequent studies showed that other metathesis catalysts are also able to promote ATRA reactions. ${ }^{[6 j, 6 \mathrm{~m}, 18]}$ First examples of sequential metathesis-ATRC reactions were described in 1995.[19] It was demonstrated that the alkylidene complex

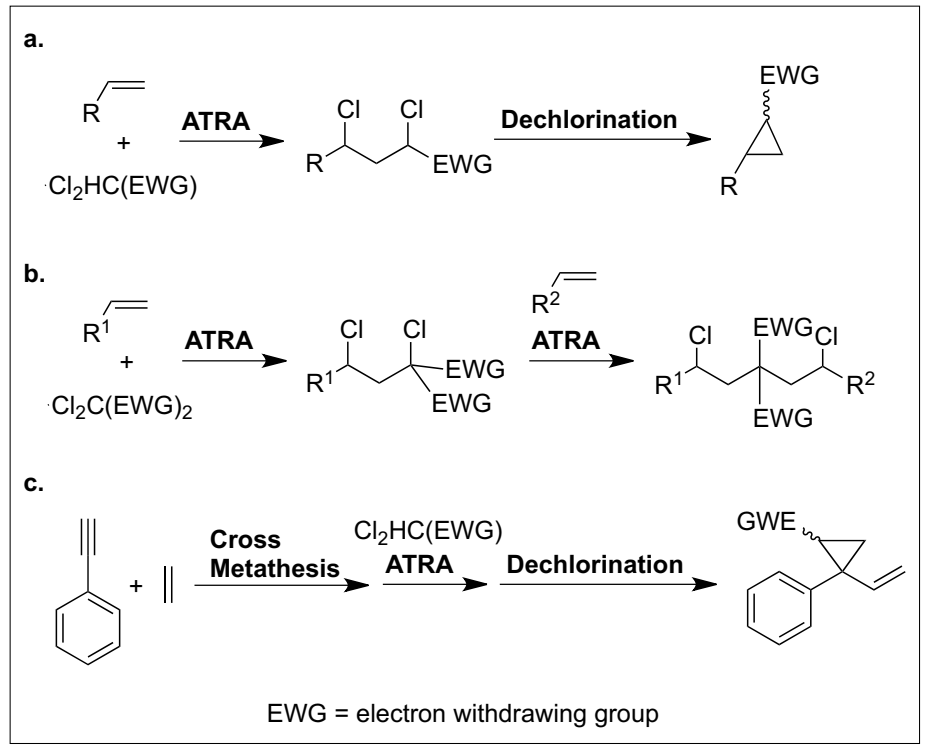

Scheme 3. Sequentia reactions involving Ru-catalyzed ATRA reactions. 
$\mathrm{RuCl}_{2}(=\mathrm{CPh})\left(\mathrm{PPy}_{3}\right)_{2}$ is able to catalyze ring-closing metathesis-ATRC cascades to gives bicyclic lactams. ${ }^{[4 a]}$ These tandem reactions can be combined with palladiummediated rearrangements, ${ }^{[20]}$ and a bimetallic Ru complex was employed instead of the Grubbs catalysts. [21] Intermolecular cross-metathesis reactions were also combined with ATRC reactions. ${ }^{[22]}$ We have shown that it is possible to combine enyne cross-metathesis reactions with ATRA reactions in one pot to give 1,5-dichloropent2-ene derivatives. ${ }^{[23]}$ The latter are interesting starting materials for the synthesis of vinylcyclopropanes by dechlorination (Scheme 3c).

\section{Conclusions}

ATRA and ATRC reactions can be performed with low catalyst loadings under mild conditions using ruthenium catalysts in conjunction with reducing agents such as $\mathrm{Mg}$. The $\mathrm{Ru}$-catalyzed radical reactions can be combined with metathesis or dechlorination reactions to obtain synthetically interesting compounds in convenient one-pot procedures.

\section{Acknowledgements}

This work was supported by the Swiss National Science Foundation and by the EPFL. I am very grateful to the collaborators who have contributed to the results described in this overview.

Received: February 28, 2012

[1] a) M. S. Kharasch, E. V. Jensen, W. H. Urry, Science 1945, 102, 128; b) M. S. Kharasch, W. H. Urry, E. V. Jensen, J. Am. Chem. Soc. 1945, 67, 1626.

[2] F. Minisci, Acc. Chem. Res. 1975, 8, 165.

[3] a) J. M. Muñoz-Molina, T. R. Belderrain, P. J. Pérez, Eur. J. Inorg. Chem. 2011, 3155; b) T Pintauer, K. Matyjaszewski, Chem. Soc. Rev. 2008, 37, 1087; c) K. Severin, Curr. Org. Chem.
2006, 10, 217; d) L. Delaude, A. Demonceau, A. F. Noels, Top. Organomet. Chem. 2004, 11, 155; e) H. Nagashima in 'Ruthenium in Organic Synthesis', Ed.: S.-I. Murahashi, WILEY-VCH, Weinheim, 2004, p. 333; g) K. I. Kobrakov, A. V. Ivanov, J. Heterocyclic Chem. 2001, 37, 529; h) R. A. Gossage, L. A. van de Kuil, G. van Koten, Acc. Chem. Res. 1998, 31, 423; i) J. Iqbal, B. Bhatia, N. K. Nayyar, Chem. Rev. 1994, 94, 519.

[4] a) G. J. Rowlands, Tetrahedron 2010, 66, 1593; b) A. J. Clark, Chem. Soc. Rev. 2002, 31, 1.

[5] H. Matsumoto, T. Nakano, Y. Nagai, Tetrahedron Let. 1973, 51, 5147.

[6] For selected examples see: a) R. J. Lundgren, M. A. Rankin, R. McDonald, M. Stradiotto, Organometallics 2008, 27, 254; b) B. Dutta, E. Solari, R. Scopelliti, K. Severin, Organometallics 2008, 27, 423; c) Y. Borguet, A. Richel, S. Delfosse, A. Leclerc, L. Delaude, A. Demonceau, Tetrahedron Lett. 2007, 48, 6334; d) Y. Motoyama, S. Hanada, K. Shimamoto, H. Nagashima, Tetrahedron 2006, 62, 2779; e) L. Quebatte, E. Solari, R. Scopelliti, K. Severin, Organometallics 2005, 24, 1404; f) Y. Motoyama, S. Hanada, S. Niibayashi, K. Shimamoto, N. Takaoka, H. Nagashima, Tetrahedron 2005, 61, 10216; g) L. Quebatte, M. Haas, E. Solari, R. Scopelliti, Q. T. Nguyen, K. Severin, Angew. Chem. Int. Ed. 2005, 44, 1084; h) L. Quebatte, R. Scopelliti, K. Severin, Eur. J. Inorg. Chem. 2005, 3353; i) L. Quebatte, R. Scopelliti, K. Severin, Angew. Chem. Int. Ed. 2004, 43, 1520; j) B. T. Lee, T. O. Schrader, B. Martín-Matute, C. R. Kauffman, P. Zhang, M. L. Snapper, Tetrahedron 2004, 60, 7391; k) O. Tutusaus, S. Delfosse, A. Demonceau, A. F. Noels, C. Viñas, F. Teixidor, Tetrahedron Lett. 2003, 44, 8421; 1) O. Tutusaus, C. Viñas, R. Núñez, F. Teixidor, A. Demonceau, S. Delfosse, A. F. Noels, I. Mata, E. Molins, J. Am. Chem. Soc. 2003, 125, 11830; m) B. de Clercq, F. Verpoort, Tetrahedron Lett. 2002, 43, 4687; n) F. Simal, L. Wlodarczak, A. Demonceau, A. F. Noels, Eur. J. Org. Chem. 2001, 14, 2689; o) F. Simal, L. Wlodarczak, A. Demonceau, A. F. Noels, Tetrahedron Lett. 2000, 41, 6071.

[7] L. Quebatte, K. Thommes, K. Severin, J. Am Chem. Soc. 2006, 128, 7440 .

[8] K. Matyjaszewski, W. Jakubowski, K. Min, W. Tang, J. Huang, W. A. Braunecker, N. V. Tsarevsky, PNAS 2006, 103, 15309.

[9] a) A. D. Phillips, K. Thommes, R. Scopelliti, C. Gandolfi, M. Albrecht, K. Severin, D. F. Schreiber, P. J. Dyson, Organometallics 2011,
30, 6119; b) J. Wolf, K. Thommes, O. Briel, R. Scopelliti, K. Severin. Organometallics 2008 28, 4464; c) K. Thommes, B. Içli, R. Scopelliti, K. Severin, Chem. Eur. J. 2007, 13, 6899.

[10] M. A. Fernández-Zúmel, C. Buron, K. Severin, Eur. J. Org. Chem. 2011, 2272.

[11] a) W. T. Eckenhoff, T. Pintauer, Catal, Rev. 2010, 52, 1; b) T. Pintauer, Eur. J. Inorg. Chem. 2010, 2449.

[12] K. Thommes, G. Kiefer, R. Scopelliti, K Severin, Angew. Chem. Int. Ed. 2009, 48, 8115.

[13] Julie Risse, Mariano A. Fernández-Zúmel, Yanouk Cudré, Kay Severin, submitted.

[14] H. Nagashima, H. Wakamatsu, N. Ozaki, T. Ishii, M. Watanabe, T. Tajima, K. Itoh, J. Org. Chem. 1992, 57, 1682.

[15] S. Iwamatsu, H. Kondo, K. Matsubara, H. Nagashima, Tetrahedron 1999, 55, 1687.

[16] K. Thommes, M. A. Fernández-Zúmel, C. Buron, A. Godinat, R. Scopelliti, K. Severin, Eur. J. Org. Chem. 2011, 249.

[17] a) F. Simal, A. Demonceau, A. F. Noels, Tetrahedron Lett. 1999, 40, 5689; b) J. A Tallarico, L. M. Malnick, M. L. Snapper, J. Org. Chem. 1999, 64, 344.

[18] a) J. Faulkner, C. D. Edlin, D. Fengas, I. Preece, P. Quale, S. N. Richards, Tetrahedron Lett. 2005, 46, 2381; b) B. Schmidt, M. Pohler, B. Costisella, J. Org. Chem. 2004, 69, 1421; c) P. Quale, D. Fengas, S. Richards, Synlett 2003, 1797; e) B. De Clercq, F. Verpoort, J. Organomet. Chem. 2003, 672, 11; d) T. Opstal, F. Verpoort, New J. Chem. 2003, 27, 257; e) B. De Clercq, F. Lefebvre, F. Verpoort, Appl. Catal. A 2003, 247, 345.

[19] a) B. A. Seigal, C. Fajardo, M. L. Snapper, J. Am. Chem. Soc. 2005, 127, 16329; b) B Schmidt, M. Pohler, J. Organomet. Chem. 2005, 690, 5552.

[20] a) F. I. McGonagle, L. Brown, A. Cooke, A Sutherland, Tetrahedron Lett. 2011, 52, 2330; b) F. I. McGonagle, L. Brown, A. Cooke, A. Sutherland, Org. Biomol. Chem. 2010, 8, 3418.

[21] Y. Borguet, X. Sauvage, G. Zaragoza, A. Demonceau, L. Delaude, Beilstein J. Org. Chem. 2010, 6, 1167.

[22] C. D. Edlin, J. Falkner, P. Quale, Tetrahedron Lett. 2006, 47, 1145; b) C. D. Edlin, J. Faulkner, D. Fengas, M. Helliwell, C. K. Knight, D. House, J. Parker, I. Preece, P. Quale, J. Raftery, S. N. Richards, J. Organomet. Chem. 2006, 691, 5375 .

[23] G. Kiefer, J. Ruiz, E. Solari, G. Hilt, K. Severin Eur. J. Org. Chem. 2012, 930. 